\title{
Analysis of Trace Elements in Leaves Using Laser-Induced Breakdown Spectroscopy
}

\author{
Xu Zhang, Mingyin Yao*, Muhua Liu, and Zejian Lei \\ Optics-Electronics Application of Biomaterials Lab, College of Engineering, \\ Jiangxi Agricultural University, Nanchang, Jiangxi 330045, China \\ $\{z \times 8475396$, mingyin800\}@126.com
}

\begin{abstract}
Laser-Induced Breakdown Spectroscopy (LIBS) is a new way to analyze the plant ecology. The experimental used a Q-switched Nd:YAG laser to be the laser source and equipped with an eight-channel model spectrometer which's wavelength range between 200 and $1100 \mathrm{~nm}$. Studying the spectrum of the air-drying leaves and the nature leaves and detected the elements which contain $\mathrm{Fe}, \mathrm{Ca}, \mathrm{Na}, \mathrm{Mg}, \mathrm{K}, \mathrm{Cu}, \mathrm{Al}$ and $\mathrm{Mn}$. Displaying the list which shows the all spectrum and elements. Refer to $\mathrm{Fe}$ as the benchmark, obtain the relative content of trace elements. At the same time, this technology can be employed for food safety and environment pollution evaluation. It will be the based for studying the portable LIBS instrument of detecting the pollution of heavy metal.
\end{abstract}

Keywords: LIBS, Trace element, Leaves, Air-drying, Relative content.

\section{$1 \quad$ Introduction}

Laser-Induced Breakdown Spectroscopy (LIBS) is a new technology which can analyse the constitution and concentration of the matter. It is a laser-based omnipotent molecular and elemental analysis tool. This technology doesn't need to deal with the samples in complicated. And it can anslyse several elements at the same time. LIBS is non-destructive, rapid detection, high sensitivity, on-site and online analysis. It is widely applied in the detection of trace elements in solid, liquid and gas, such as soil[1] alloy steel[2] solution[3] and even in biomedicine[4]. There are some reports about analysing the leaf by laser-induced breakdown spectroscopy. Lidiane[5] and other partners used LIBS to analyse the leaf by neuro-genetic approach. Miloslav[6] and his partners analysed the crop leaves and detected six certified reference materials of leaf tissues by LIBS.

Recently, in order to develop the level of LIBS, there are some experiments include nanosecond, femtosecond, monopulse, dipulse[7-8]. Although LIBS has been made a very great achievement in the analysis of material. But there are still many problems to be solved, such as how to decrease the matrix effect[9] in detecting several elements and how to increase the signal to noise radio.

\footnotetext{
* Corresponding author.
} 
In our work, we analyzed trace elements in leaf by LIBS. This works about the analysis of leaf can help to study the information of tea leaf and tobacco in the future. In this paper, first of all, we introduce the information of sample and the experimental setup. We displayed the results of trace elements analysis and all spectral lines to the correspanding elements table in leaves by LIBS.

\section{Experimental Setup}

In our experiments, we used a Q-switched Nd:YAG laser (BeamTech, Nimma-200, China) to be the laser source and the experimental setup includes an eight-channel model spectrometer, mirror, DG535, lens, optical fiber(1.5 m length, 400 um core diameter), fiber-optical probe, rotating stage, computer as shown in figure 1.

The fundamental wavelength of the laser is $1064 \mathrm{~nm}$. And other parameters about laser are $8 \mathrm{~ns}$ pulse width, $10 \mathrm{~Hz}$ repetition rate. Laser beam was reflected to $45^{\circ}$ by the mirror, and through the mirror with a hole focused on the sample which were put on the rotating stage by the lens which's focal length is $200 \mathrm{~nm}$. The plasma was launched and focused on the fiber-optical probe through the lens which's focal length is $100 \mathrm{~nm}$. The probe position is adjustable. We used an eight-channel model AVS-Rackmount-USB2 spectrometer(Avantes, France) which's wavelength range between 200 and $1100 \mathrm{~nm}$ to collect and analyse the plasma emission. The spectrometer has eight wavebands which is 200-317nm, 315-417nm, 415-499nm, 497-565nm, 563-673nm, 671-750nm, 748-931nm, $929-1100 \mathrm{~nm}$. The integration time and the delay time respectively were $2 \mathrm{~ms}$ and $1.28 \mathrm{us}$ by taking the signal-background ratio and signal-noise ratio into account.

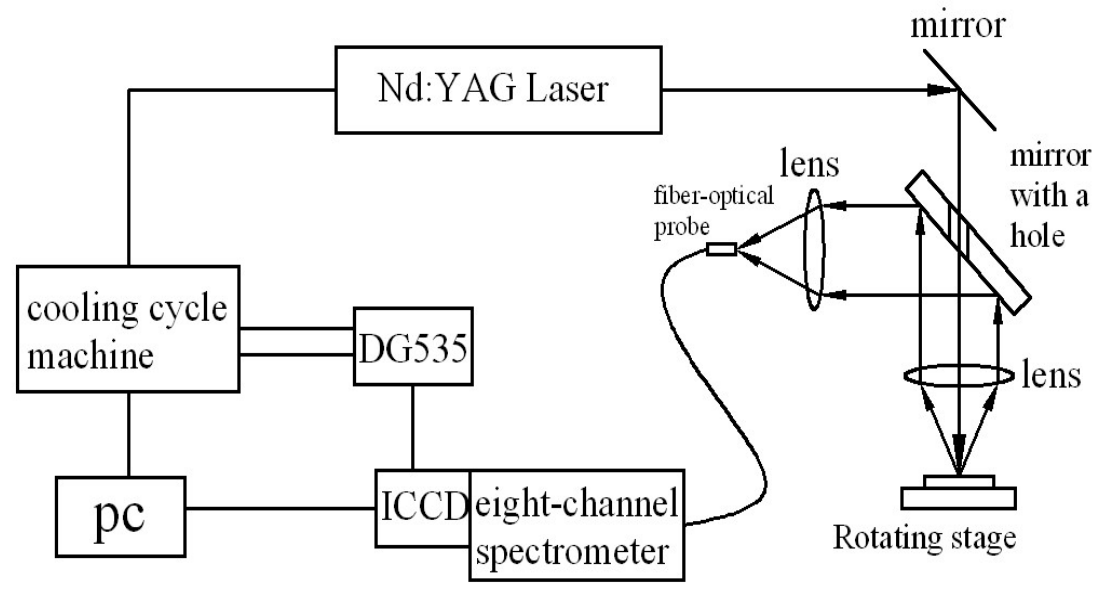

Fig. 1. LIBS experimental setup

\section{Experimental Results and Analysis}

The leaves came from the ecological orchard of Jiangxi Agricultural University. We picked the leaves in different orange trees. And then we washed the leaves by the 
deionized water. The leaves were divided into two parts, a part of all was wiped dry using filter paper, the others was dry by air drying in the air. Because the laser would produce the points which the laser hit on samples into high temperature, we used a rotating stage in order to make the effects of the laser in different points.

The figure 2 shows that a part of the spectra of capsicum in leaves. Refer to the NIST atomic database[10] and the spectral data of the elements from the papers[11-13], we obtain the specific wavelength of trace elements and analysed all peak of waves showing table 1 . From the table 1, we can find several elements such as $\mathrm{Fe}, \mathrm{Ca}, \mathrm{Na}, \mathrm{Mg}$, $\mathrm{K}, \mathrm{Cu}, \mathrm{Al}, \mathrm{Mn}$. The spectrum of Fe is most, reaching 61. At the same time, the elements $\mathrm{C}, \mathrm{H}, \mathrm{O}, \mathrm{N}, \mathrm{Cl}$ were detected by LIBS. But these elements which were detected maybe were in the air. In addition, we detected Mo which was the indispensable element in plants. Because Fe was the most element and spectrum. We choose Fe for the datum to compared with other elements.

As shown in table 2, the intensity of $\mathrm{Na}$ is strongest of all. According to the intensity of spectrum being proportional to the concertration, we can obtain the conclusion that content of $\mathrm{Na}$ is the highest in leaves. The intensity of the same elements in air-drying leaves is stronger than in nature leaves. It explaines that water in leaves will affect the detection of elements. But the spectral intensity of $\mathrm{Al}$ and $\mathrm{Na}$ almost is the same between air-drying and nature. The water has a little effect to $\mathrm{Al}$ and $\mathrm{Na}$ in leaves.
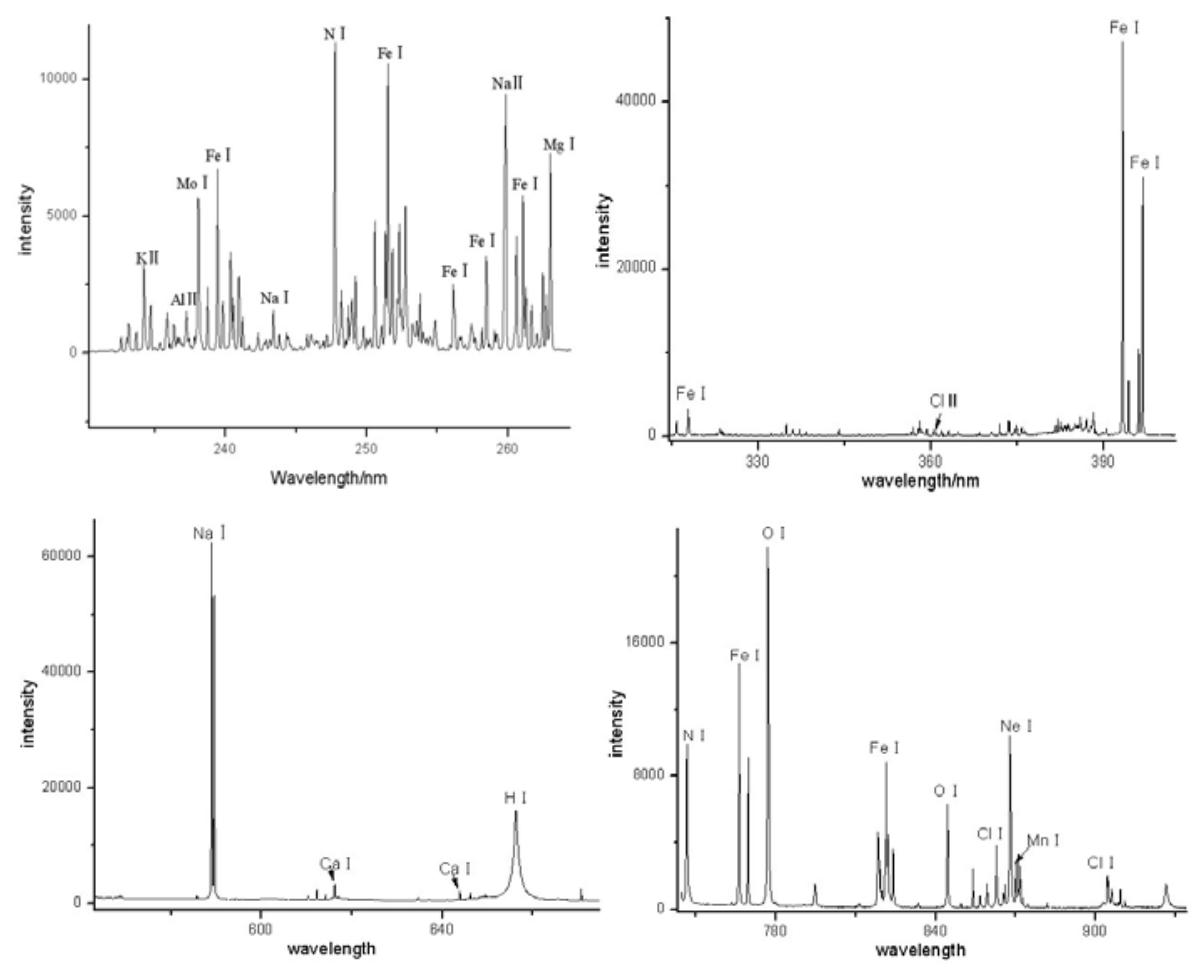

Fig. 2. A part of spectrum in leaves 
Table 1. The spectrum of LIBS in leaves

\begin{tabular}{|c|c|c|c|c|c|c|c|}
\hline $\begin{array}{c}\text { Wavelen- } \\
\text { gth/nm }\end{array}$ & $\begin{array}{c}\text { Elem- } \\
\text { ents }\end{array}$ & $\begin{array}{c}\text { Waveleng- } \\
\text { th } / \mathrm{nm}\end{array}$ & $\begin{array}{c}\text { Elem- } \\
\text { ents }\end{array}$ & $\begin{array}{c}\text { Waveleng- } \\
\text { th /nm }\end{array}$ & $\begin{array}{c}\text { Elem- } \\
\text { ents }\end{array}$ & $\begin{array}{c}\text { Waveleng- } \\
\text { th } / \mathrm{nm}\end{array}$ & $\begin{array}{c}\text { Elem- } \\
\text { ents }\end{array}$ \\
\hline 232.606 & O II & 253.231 & Mo II & 381.977 & $\mathrm{He} \mathrm{I}$ & 742.361 & N I \\
\hline 233.120 & Fe II & 253.787 & Mn II & 388.193 & $\mathrm{Fe} \mathrm{I}$ & 744.219 & N I \\
\hline 233.698 & $\mathrm{Na} I I$ & 254.834 & C II & 393.263 & $\mathrm{Fe} \mathrm{I}$ & 746.814 & N I \\
\hline 234.212 & K II & 256.125 & $\mathrm{Fe} \mathrm{I}$ & 396.775 & $\mathrm{Fe} \mathrm{I}$ & 766.340 & $\mathrm{Fe} \mathrm{I}$ \\
\hline 234.725 & C II & 257.412 & $\mathrm{Ne} I I$ & 422.742 & $\mathrm{Fe} \mathrm{I}$ & 769.678 & $\mathrm{Fe} \mathrm{I}$ \\
\hline 235.365 & Fe II & 258.452 & $\mathrm{Fe} \mathrm{I}$ & 438.406 & $\mathrm{Na} I I$ & 777.072 & O I \\
\hline 235.877 & K II & 259.854 & $\mathrm{Na} I I$ & 445.518 & $\mathrm{Na} I I$ & 794.791 & O I \\
\hline 236.325 & Fe II & 260.584 & $\mathrm{Fe} I I$ & 498.216 & $\mathrm{Fe} \mathrm{I}$ & 818.404 & N I \\
\hline 237.218 & $\mathrm{Al} \mathrm{I}$ & 261.070 & $\mathrm{Fe} \mathrm{I}$ & 517.303 & $\mathrm{Fe} \mathrm{I}$ & 821.545 & $\mathrm{Fe} \mathrm{I}$ \\
\hline 238.047 & Mo I & 262.463 & $\mathrm{Fe} \mathrm{I}$ & 518.410 & $\mathrm{Fe} \mathrm{I}$ & 824.163 & N I \\
\hline 238.747 & Mg II & 262.705 & $\mathrm{Fe} \mathrm{I}$ & 520.880 & $\mathrm{Fe} \mathrm{I}$ & 844.481 & O I \\
\hline 239.446 & $\mathrm{Fe} \mathrm{I}$ & 263.008 & $\mathrm{Mg} \mathrm{I}$ & 527.061 & $\mathrm{Fe} \mathrm{I}$ & 849.626 & $\mathrm{Fe} \mathrm{I}$ \\
\hline 239.827 & $\mathrm{Ca} I$ & 267.634 & Mn I & 532.857 & Fe I & 854.050 & $\mathrm{Fe} \mathrm{I}$ \\
\hline 240.335 & $\mathrm{Cu}$ II & 273.859 & $\mathrm{Na} I I$ & 537.208 & $\mathrm{Fe} \mathrm{I}$ & 856.662 & N II \\
\hline 240.969 & $\mathrm{Na} I I$ & 274.564 & $\mathrm{Fe} \mathrm{I}$ & 541.031 & $\mathrm{Fe} \mathrm{I}$ & 859.256 & $\mathrm{Fe} \mathrm{I}$ \\
\hline 241.222 & $\mathrm{Fe} \mathrm{I}$ & 275.502 & $\mathrm{Fe} \mathrm{I}$ & 553.604 & K II & 862.839 & $\mathrm{Cl} \mathrm{I}$ \\
\hline 242.297 & Fe II & 279.463 & $\mathrm{Fe} \mathrm{I}$ & 558.914 & $\mathrm{Ca} \mathrm{I}$ & 866.025 & N II \\
\hline 243.370 & $\mathrm{Na} \mathrm{I}$ & 280.157 & Al II & 568.837 & $\mathrm{Na} \mathrm{I}$ & 867.923 & $\mathrm{Ne} I$ \\
\hline 244.315 & $\mathrm{Na} I I$ & 285.095 & $\mathrm{Na} I I$ & 585.729 & $\mathrm{Ca} I$ & 870.169 & Mn I \\
\hline 245.760 & $\mathrm{Fe} \mathrm{I}$ & 288.046 & $\mathrm{Fe} \mathrm{I}$ & 588.977 & $\mathrm{Na} \mathrm{I}$ & 871.063 & N II \\
\hline 246.074 & $\mathrm{Na} I I$ & 301.973 & $\mathrm{Fe} I \mathrm{II}$ & 589.571 & $\mathrm{Fe} \mathrm{I}$ & 871.777 & $\mathrm{Mg} \mathrm{I}$ \\
\hline 247.201 & Mo I & 308.113 & C II & 610.303 & $\mathrm{Fe} \mathrm{I}$ & 881.872 & $\mathrm{Fe} \mathrm{I}$ \\
\hline 247.764 & N II & 309.167 & $\mathrm{Fe} \mathrm{I}$ & 612.246 & $\mathrm{Ca} \mathrm{I}$ & 904.486 & $\mathrm{Cl} \mathrm{I}$ \\
\hline 248.201 & Fe I & 315.809 & $\mathrm{Fe} \mathrm{I}$ & 614.173 & Fe I & 909.387 & $\mathrm{Fe} \mathrm{I}$ \\
\hline 248.700 & $\mathrm{Fe} \mathrm{I}$ & 317.849 & $\mathrm{Fe} \mathrm{I}$ & 616.203 & $\mathrm{Ca} \mathrm{I}$ & 911.025 & O II \\
\hline 248.949 & Fe II & 334.884 & O II & 643.895 & $\mathrm{Ca} \mathrm{I}$ & 926.633 & O I \\
\hline 249.199 & $\mathrm{Fe} \mathrm{I}$ & 343.986 & $\mathrm{Fe} \mathrm{I}$ & 646.244 & $\mathrm{Ca} I$ & 938.644 & $\mathrm{Fe} \mathrm{I}$ \\
\hline 249.759 & Fe II & 358.042 & $\mathrm{Fe} \mathrm{I}$ & 656.229 & H I & 940.518 & $\mathrm{Fe} \mathrm{I}$ \\
\hline 250.565 & $\mathrm{Fe} \mathrm{I}$ & 359.263 & $\mathrm{Fe} \mathrm{I}$ & 670.770 & $\mathrm{Fe} \mathrm{I}$ & 945.993 & N I \\
\hline 251.064 & Fe II & 360.478 & $\mathrm{Cl}$ II & 693.816 & K I & 962.024 & C I \\
\hline 251.498 & $\mathrm{Fe} \mathrm{I}$ & 361.792 & $\mathrm{Fe} \mathrm{I}$ & 714.761 & $\mathrm{Fe} \mathrm{I}$ & 965.786 & C I \\
\hline 251.808 & $\mathrm{Fe} \mathrm{I}$ & 363.048 & $\mathrm{Ca} I$ & 715.673 & O I & 1011.511 & N I \\
\hline 252.304 & O II & 364.713 & Mn I & 720.172 & $\mathrm{Ca} \mathrm{I}$ & 1053.882 & N I \\
\hline 252.737 & $\mathrm{Fe} \mathrm{I}$ & 371.923 & Mo I & 732.544 & $\mathrm{Ca} \mathrm{I}$ & & \\
\hline
\end{tabular}


Table 2. The trace elements' specific wavelengths, average spectral intensity and the ratio

\begin{tabular}{|c|c|c|c|c|c|}
\hline \multirow{2}{*}{$\begin{array}{l}\text { Trace } \\
\text { element }\end{array}$} & \multirow{2}{*}{$\begin{array}{c}\text { Specific } \\
\text { wavelength } \\
(\mathrm{nm})\end{array}$} & \multicolumn{2}{|c|}{$\begin{array}{c}\text { Average spectral } \\
\text { intensity }\end{array}$} & \multirow{2}{*}{$\begin{array}{l}\text { The ratio } \\
\text { of } \\
\text { air-drying } \\
\text { to nature }\end{array}$} & \multirow{2}{*}{$\begin{array}{c}\text { The ratio of } \\
\text { element to Fe } \\
\text { in Air-drying } \\
\text { leaves }\end{array}$} \\
\hline & & Air-drying & Nature & & \\
\hline $\mathrm{Fe}$ & 422.743 & 10147.72 & 7485.75 & 1.36 & 1.00 \\
\hline $\mathrm{K}$ & 234.212 & 3225.88 & 2050.70 & 1.57 & 0.32 \\
\hline $\mathrm{Al}$ & 237.218 & 1563.05 & 1525.63 & 1.02 & 0.15 \\
\hline $\mathrm{Mg}$ & 263.008 & 7307.31 & 4734.69 & 1.54 & 0.72 \\
\hline $\mathrm{Na}$ & 588.977 & 62501.57 & 64445.97 & 0.97 & 6.16 \\
\hline $\mathrm{Ca}$ & 643.895 & 3152.75 & 1782.66 & 1.77 & 0.31 \\
\hline Mn & 870.169 & 2755.64 & 1692.33 & 1.63 & 0.27 \\
\hline
\end{tabular}

\section{Conclusion}

In this paper, we used the Laser-Induced Breakdown spectroscopy to detect the trace elements in leaves and obtained the spectrum of $\mathrm{Fe}, \mathrm{Ca}, \mathrm{Na}, \mathrm{Mg}, \mathrm{K}, \mathrm{Cu}, \mathrm{Al}, \mathrm{Mn}, \mathrm{C}, \mathrm{H}$, $\mathrm{O}, \mathrm{N}, \mathrm{Cl}$. Concertration of $\mathrm{Na}$ is the highest. And we compared the air-drying leaves with nature leaves and got the conclusion that the water will affect the detection of elements in leaves. Experiment shows LIBS can quickly analyse the relative content of trace elements in leaves.

\section{References}

1. Ferreira, E.C., Milori, D.M.B.P., Ferreira, E.J., Da Silva, R.M., Martin-Neto, L.: Artificial neural network for $\mathrm{Cu}$ quantitative determination in soil using a portable laser induced breakdown spectroscopy system. Spectrochimica Acta Part B 63, 1216-1220 (2008)

2. Sun, L.-X., Yu, H.-B., Xin, Y., Cong, Z.-B.: Quantitative Analysis of Mn and Si of Alloy Stseels by Laser-Induced Breakdown Spectroscopy. Spectroscopy and Spectral Analysis 30(12), 3186-3190 (2010)

3. Wu, J.-L., Fu, Y.-X., Li, Y.: Detection of Metal lons in Water Solution by Laser Induced Breakdown Spectroscopy. Spectroscopy and Spectral Analysis 28(9), 1979-1982 (2008)

4. Liu, X.-Y., Wang, Z.-Y., Hao, L.-Q.: Application of laser induced breakdown spectroscopy technology in biom edicine field. Laser Technology 32(2) (April 2008)

5. Nunes, L.C., da Silva, G.A., Trevizan, L.C.: Simultaneous optimization by neuro-genetic approach for analysis of plant materials by laser induced breakdown spectroscopy. Spectrochimica Acta Part B 64, 565-572 (2009)

6. Pouzar, M., Cernohorsky, T., Prusova, M., Prokopcakova, P., Krejcova, A.: LIBS analysis of crop plants. Journal of Analytical Atomic Spectrometry 24, 953-957 (2009)

7. Samek, O., Lambert, J., Hergenroder, R., Liska, M., Kaiser, J., Novotny, K., Kukhlevsky, S.: Femotosecond laser spectrochemical analysis of plant samples. Laser Physics, Lett. 3(1), 21-25 (2006) 
8. Zhang, Q., Xiong, W., Chen, Y.-Q., Li, R.-H.: Rapid Measurement of Trace Mercury in Aqueous Solutions with Optical-Electrical Dual Pulse LIBS Technique. Spectroscopy and Spectral Analysis 31(2), 521-524 (2011)

9. Xie, C.-L., Lu, J.-D., Li, J.: Matrix effect on Laser-Induced Breakdown Spectroscopy of fine coal. Journal of Engineering Thermophysics 29(2) (February 2008)

10. NIST, http://www.physics.nist.gov/PhysRefData/ASD/lines_form. html

11. Zhang, D.-C., Ma, X.-W., Zhu, X.-L., Bin, L., Zu, K.-L.: Application of laser-induced breakdown spectroscopy in analyzing micro elements in three kinds of fruit samples. Acta Physica Sinica 57(10) (October 2008)

12. Zhang, D.-C., Ma, X.-W., Zhu, X.-L., Li, B., Zu, K.-L.: Microelements in Potato and Lily Samples Studied by Laser-Induced Breakdown spectroscopy Technology. Spectroscopy and Spectral Analysis 29(5), 1189-1192 (2009)

13. Sun, D.-X., Su, M.-G., Dong, C.Z.: Quantitative analysis of element concentration in Al alloy by using laser-induced breakdown spectroscopy. Acta Physica Sinica 59(7) (July 2010) 